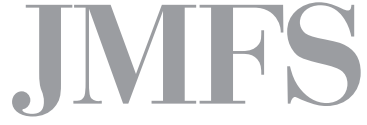

Journal of Management and Financial Sciences
Volume XII

Issue 36 (March 2019)

pp. 103-122

Warsaw School of Economics

Collegium of Management and Finance

Tomasz Dorożyński

Department of International Trade

University of Lodz

Bogusława Dobrowolska

Department of Economic and Social Statistics

University of Lodz

Anetta Kuna-Marszałek

Department of International Trade

University of Lodz

\title{
Institutional quality as a determinant of FDI inflow: the case of Central and Eastern European countries
}

\begin{abstract}
In the article, we focus on the institutional aspects and their role in attracting foreign direct investment (FDI). Hence, the objective of the paper is to assess institutional quality in 17 countries of Central and Eastern Europe and to examine the relationship between the quality of institutions measured with the synthetic index of institutional quality and FDI inflow.

This study is structured as follows. First, it explores the existing literature on factors of investment attractiveness, paying special attention to the importance of institutional efficiency. Then, we discuss FDI inflow into Central and Eastern European countries and select diagnostic variables that will later be used as the basis for the construction of a synthetic index of institutional quality (SIIQ). By composing a ranking of countries based on estimated values of the index, we could identify countries of similar institutional quality. In the last stage we analyse the correlation between SIIQ in individual countries and FDI inward stock as \% of GDP. At the end we present conclusions.
\end{abstract}

Keywords: FDI, institutions, institutional quality, synthetic index of institutional quality (SIIQ), CEECs JEL Classification Codes: F21, F23 


\section{Introduction}

The institutional environment is one of the factors of paramount importance for a country's FDI attractiveness. Its relevance has been realised for quite a long time; however, it was not until the 1990 s that FDI researchers began to attach greater importance to it [Bailey, 2018; Daniele, Marani, 2006; Bénassy-Quéré, Coupet, Mayer, 2005]. There are some reasons why the quality of institutions does matter to foreign investors. Firstly, according to the institutional theory, enterprises operate in a complex and unstable environment, which is why their decisions are largely based on the performance of institutions that impact the development of the investment environment [Francis, Zheng, Mukherji, 2009, p. 568]. Policymakers can influence capital structure and investment decisions, and thus the cost of capital and company value, by controlling corruption, adopting quality regulations and ensuring the rule of law. Secondly, since policymakers may impact the capital structure of firms, by the same token they may determine the quality of corporate governance at company level [Lemma, Negash, 2013, p.1115]. Finally, and most importantly, the presence of a high-quality institutional setting tends to add more credibility and security to MNEs, which translates into lower investment transaction costs (sunk costs included) [Daniele, Marani, 2006, p. 25].

Thus, we may argue that researchers agree that institutions (whether regional, national or sub-national) shape the nature of business by providing the framework of opportunities and constraints within which economic activity takes place [Nielsen, Asmussen, Weatherall, $2017,66]$, which implies that the quality of the host country institutions should impact FDI location decisions.

Acemoglu, Johnson and Robinson [2004, pp. 1-2] stress that, in most instances, countries where the quality of institutions is high (by which we understand effective rule of law, good business climate, more secure property rights and market-friendly social norms) are better positioned to attract investment and participate in trade, resulting in better growth performance over the long run. In turn, Hausmann and Fernández-Arias [2000, p. 27] suggest that countries representing "lower" institutional quality paradoxically attract more foreign capital because there are investors who prefer doing business in a more complex investment environment because the cost of entering such markets is lower compared to other economies. According to Levchenko [2004, pp. 812-813], institutional differences between countries may thus be a source of comparative advantages. It implies that some sectors are more "institution-intensive" than others, and that this could be a source of more trade or investment flows.

Therefore, apparently, the importance of institutions in attracting FDI is an issue of high relevance. At the same time, we need to bear in mind that changing the governance framework is extremely difficult. Kaufman, Kraay, and Mastruzzi [2005, p. 24] estimate that over the eight-year period, between 1996 and 2004, only ca. 5-7\% of the 200-plus countries in their database experienced a substantial change (for better or worse) in governance. Hence, if this is an important determinant of attracting FDI, it will be decisive for the size of FDI inflows 
over a long-term. On top of that, many researchers [Jude, Levieuge, 2015; Busse, Hefeker, 2007; Ali et al., 2010] believe that institutions have the power to impact not only the quantity, but also the quality of FDI. That is because foreign companies are non-homogeneous and produce different knowledge-spillover effects. Therefore, poor institutional quality is likely to attract low-technology, resource-exploiting FDI which offers limited growth potential [Jude, Levieuge, 2015, p. 6].

The majority of the publications on relationships between institutions and FDI flows focus on the institutions in the host country [Bonni, Quan, Meenakshi, 2012; Mohamed, Sidiropulos, 2010; Daude, Stein, 2007; Globerman, Shapiro, 2003]. Nevertheless, we may also come across publications addressing the impact of institutional quality upon OFDI [Klimek, 2015; Wang et. al., 2014; Kolstad, Wiig, 2012], which examine whether a better institutional framework might reduce undesirable outflows of capital and if the quality of those institutions may impact FDI effectiveness in host countries. Moreover, we need to observe that most researchers focus on the level of FDI; however, some, like Buchanan, Le and Rishi [2012, p. 81], also postulate research studies in the area of the volatility of FDI inflows.

The relationship between institutional quality and FDI inflows is illustrated by many factors, such as democratic institutions and political stability [e.g. Jensen 2008; Busse, 2004], corruption [e.g. Habib, Zurawicki, 2010, Al-Sadig, 2009; Globerman, Shapiro, 2003], tax policies [Feld, Heckemeyer, 2008; Bénassy-Quéré, Fontagné, Lahrèche-Révil, 2003], property rights [Tanaka, Iwasako, 2014; Khan, Samad, 2010], or security [Essien et al., 2015; Stoian, Vickerman, 2005]. Due to the multiplicity of factors that shape the abovementioned institutional quality, the literature on its impact upon FDI can be divided into three strands [Kurul, Yalta, 2017 , p. 2]. The first one focuses mainly on identifying the effects of a specific institutional dimension, such as corruption or the political regime on FDI. The second one analyses the importance of different dimensions of institutional quality. Finally, the third one explores the effect of a composite institutional indicator, which is constructed by combining different dimensions of institutional variables.

Empirical results are vague, because it is hard to measure institutional factors. The reason may be that various researchers use different measures of institutional quality and look at different types of data (investing firms versus aggregate FDI inflows) [Walsh, Yu, 2010] or differently define individual factors of institutional quality. As Ali et al. [2010, pp. 204-205] rightfully observe, measurement problems also emerge when a single factor is used to capture a broad, complex phenomenon such as institutions. Foreign investors are likely to base their investment decisions on overall institutional quality rather than on a single institutional aspect such as political stability or corruption. By using only one indicator in the analyses, we are most likely to underestimate the role of institutions in determining FDI inflows.

The majority of studies find inward FDI to be significantly influenced by the quality of institutional variables [Daude, Stein, 2007; Pournarakis, Varsakelis, 2002; Fabry et al., 2006]. However, there are researchers [e.g. Akçay, 2001] who did not observe any clear relationship between institutions and FDI. Some authors argue that political stability, corruption and crime 
rates impact FDI more than any other institutional factor [Tuman, Emmert, 2009]. Others claim that political stability has little potential to attract investments [Egger, Winner, 2005; Jaspersen et al. 2000], and some have observed a positive relationship between corruption and the inflow of FDI [Egger, Winner, 2005].

For our study, we selected 17 countries of Central and Eastern Europe (CEE). The term Central and Eastern Europe and its geographical scope is defined in many sorts of ways in the existing literature [Bański, 2008; Ostergren, Rice, 2004; Halecki, 1994]. For the needs of this publication, we adopted the most commonly recognised scope of the region, which includes the Visegrad Group countries (Poland, the Czech Republic, Slovakia, and Hungary), the Baltic States (Lithuania, Latvia, and Estonia), countries of the former Yugoslavia (Bosnia and Herzegovina, Croatia, Macedonia, Montenegro, Serbia, and Slovenia), Romania, Bulgaria, Albania, and Ukraine. In selecting the countries, we were guided by three criteria applied in conjunction: firstly, by their geographical location; secondly, by political convergence with European and Transatlantic structures; and thirdly, by an ongoing or recently completed economic transformation. For that reason, countries such as Austria, Switzerland or Belarus were not considered, while Kosovo is not included in the Global Competitiveness Index ranking. We analysed several dozen variables that reflect the efficiency of their institutional setup. By correlating these variables with FDI stock, we will be able to assess not only if, but, first and foremost, which institutional factors may determine the investment attractiveness of countries.

\section{FDI in Central and Eastern European countries}

Central and Eastern Europe is often seen by investors as one entity, even though the countries of the region very much differ with respect to their ability to attract FDI (Figure 1). Poland, the Czech Republic, and Hungary are the most effective in successfully competing for foreign investors. In 2016, the total value of the FDI inward stock exceeded the value of FDI stock in all the other countries covered by the study taken together (ca. USD 380 bn compared to USD 342 bn).

However, the examined values look different when we take account of the FDI inward stock as \% of GDP (Figure 2). Then, we find out that Montenegro is an undisputed leader (113\%). Estonia, Bulgaria and Serbia managed to attract FDI stock equivalent of ca. $80 \%$ of their GDP. In this ranking Poland occupies the $14^{\text {th }}$ position among 17 countries $(39.8 \%)$. At the bottom of the ranking there is Slovenia with the share of FDI stock in GDP not higher than $30 \%$. It is difficult to find regularities in this ranking that would address, e.g., the impact of the size of the country or the EU membership. 
Figure 1. FDI inward stock in 2016 (in millions of USD)

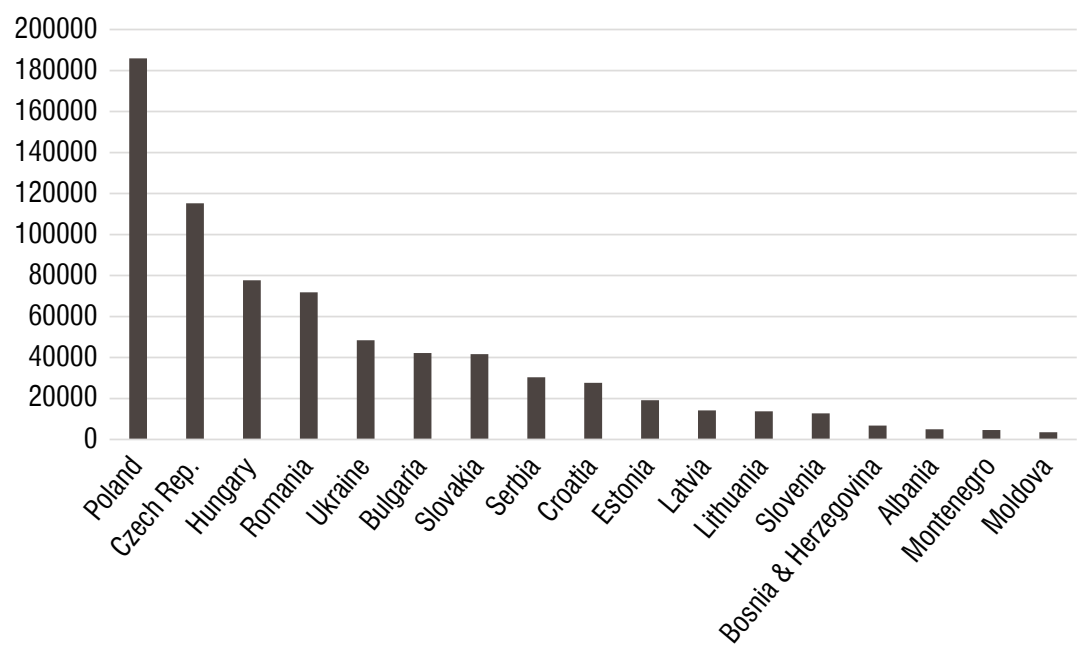

Source: World Investment Report, UNCTAD (2017).

Figure 2. FDI inward stock as \% of GDP in 2016

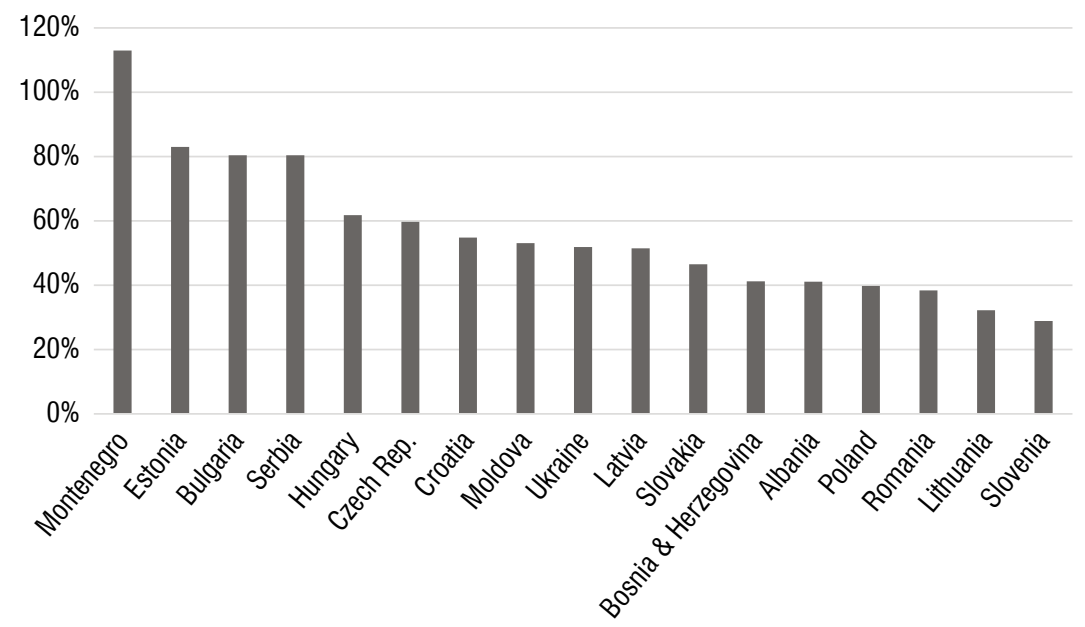

Source: World Investment Report, UNCTAD (2017).

\section{Institutional quality assessment in CEE countries based on the Global Competitiveness Index}

Institutional performance of Central and Eastern European countries was assessed based on the Global Competitiveness Index (GCI). It has regularly been published by the World Economic Forum since 1979. The GCI started with only one ranking, the Competitiveness Index, prepared under the supervision of Jeffrey Sachs and designed to identify the foundations of medium and long-term rapid economic growth. Then, it gradually expanded with 
new indices. Some of them come from results of surveys conducted amongst thousands of corporate managers from almost all the countries included in the analysis (137 countries in the latest edition 2017-2018). This latest edition features only 6 countries of Central and Eastern Europe in the top 50: Estonia is the highest ranked, in $29^{\text {th }}$ place, followed by the Czech Republic (31), and Poland (39), which scored 4.85, 4.77, and 4.59, respectively, on a scale from 1 to 7 (with 7 being the highest score).

The GCI presents the results in three main categories (basic requirements, efficiency enhancers, and innovation and sophistication factors), which address twelve policy domains (pillars). Each pillar is built of at least several detailed subcategories, and then indices. Final assessment of a given economy is thus a derivative of over 100 different indicators. For our paper, we selected 23 indices, which best describe institutional quality. Most of them come from the first pillar Institutions and from its Part I Public Institutions ${ }^{1}$ (it includes 16 detailed indices). Nevertheless, we decided that some indices from other pillars also relate to institutional quality, although they have been included in other fields (e.g. education, market efficiency or R\&D innovation - Figure 3). Many other authors also believe that they inform about institutional quality of a given country, e.g.:

1) quality of the educational system [Alesina, Perotti, 1996] - we may expect that more educated population demands more transparent and dynamic institutions and permits to build them;

2) effectiveness of antimonopoly policy [Petersen, 2011] - the better antitrust regimes protect the market against monopolies or cartels, the more intense competition between different suppliers, and institutions are seen as better performing;

3) effect of taxation on incentives to invest and to work [Moore, 1998; Fatica, 2009] - a sound tax system enables the consolidation of a social contract that gives rise to a more demanding relationship between state and citizens;

4) relevance of trade barriers [Rodrik et al., 2004; Rigobon, Rodrik, 2004] - international openness creates a more dynamic, sophisticated and demanding environment, which fuels a larger demand for good institutions; encourages a more competitive environment, and it can hinder corruption and nepotism;

5) business impact of rules on FDI [Bruno, 2008] - usually investors avoid investing in countries where regulations are unclear, often change and restrict competition. The better and more effective institutions, the better market development opportunities for the market;

6) government procurement of advanced technology products [Lee, Park, 2013] - manufacturing advanced technology products is linked, inter alia, with intellectual property rights, thus, we may expect that more respect for IPR means better perception of the quality of institutions in a given country.

1 Besides Part I in the pillar Institutions there is also Part II (Private institutions). It embraces 2 categories and 5 detailed indices, which provide the assessment of, inter alia, corporate ethics and governance standards. We have skipped it in our study and decided to focus on the assessment of the performance of public institutions. 
All of the above listed indicators help assess the institutional system of a given country from the point of view of, inter alia, the enforcement of property rights, public institutions' interference in the economy, efficiency and transparency in the public sector, quality of educational system, and labour market efficiency.

Figure 3. Key subcategories and indices of institutional quality

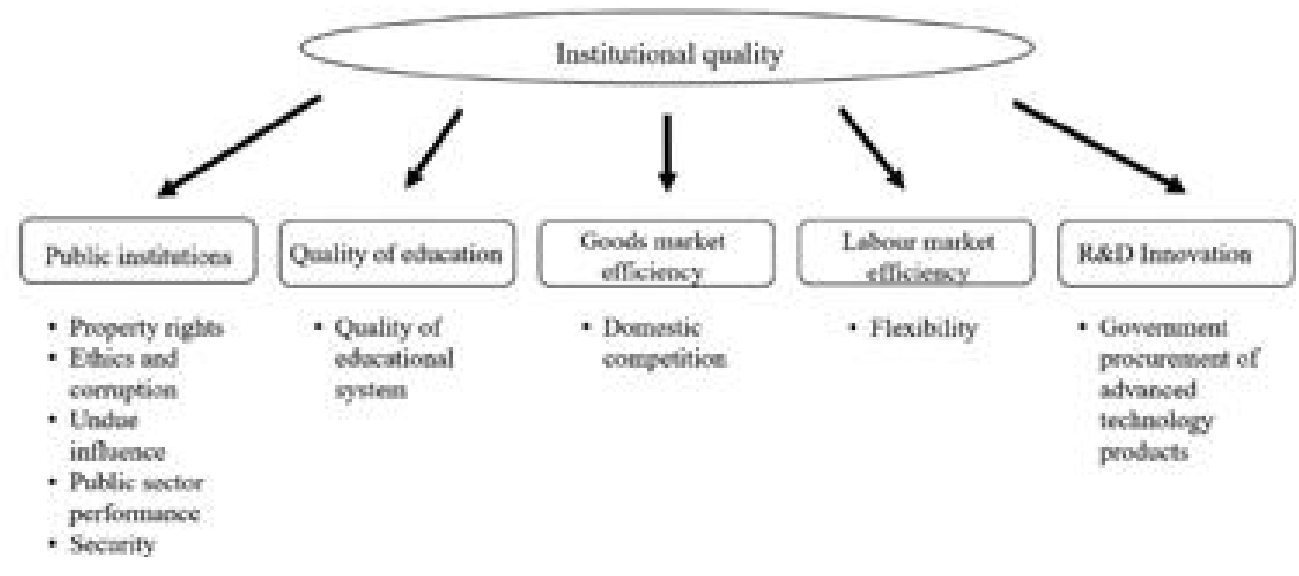

Source: own elaboration based on GCI.

\section{Preliminary data analysis - selection of diagnostic variables}

The study was intended to assess the institutional quality in 17 countries of Central and Eastern Europe and to investigate the relationship between the quality of institutions and FDI inflow. Our study was conducted in 3 stages. In the first stage we selected diagnostic variables, which served as foundations for the construction of a synthetic measure of development (SMD), which informs about institutional quality in countries covered by the study. The second stage aimed at composing a ranking of countries based on estimated SMD values. This measure helped us develop a synthetic index of institutional quality (SIIQ) for each country and identify countries at similar levels of institutional quality. In the final stage we analysed correlations between SIIQ and FDI inward stock as \% of GDP.

The first two stages of the study aimed at composing a ranking for countries of Central and Eastern Europe for the years 2016-2017 using a synthetic measure of development [Panek, 2009], which enabled the construction of a new, original indicator informing about institutional quality of each country. This way we were able to identify countries whose institutional quality is similar.

Selection of diagnostic variables is crucial for the correctness of the results obtained from the study. As we have already mentioned, in our case, variables were selected based on the Global Competitiveness Index. For this paper, we selected the most relevant, in our opinion, indicators that describe institutional quality. They come from several pillars encompassing a number of indexes (Table 1). 
Table 1. Potential diagnostic variables for institutional quality in CEECs in 2016-2017

\begin{tabular}{|c|c|}
\hline Symbol & Variable \\
\hline \multirow{2}{*}{$X_{1}$} & total synthetic indicator for the public institutions index \\
\hline & Pillar: Institutions/index: Public institutions \\
\hline $\mathrm{X}_{2}$ & Property rights \\
\hline$x_{3}$ & Intellectual property protection \\
\hline$X_{4}$ & Diversion of public funds \\
\hline$X_{5}$ & Public trust in politicians \\
\hline$X_{6}$ & Irregular payments and bribes \\
\hline$x_{7}$ & Judicial independence \\
\hline$X_{8}$ & Favouritism in decisions of government officials \\
\hline$X_{9}$ & Efficiency of government spending \\
\hline$X_{10}$ & Burden of government regulation \\
\hline$X_{11}$ & Efficiency of the legal framework in settling disputes \\
\hline$X_{12}$ & Efficiency of the legal framework in challenging regulations \\
\hline$X_{13}$ & Transparency of government policymaking \\
\hline$X_{14}$ & Business costs of terrorism \\
\hline$X_{15}$ & Business costs of crime and violence \\
\hline$X_{16}$ & Organized crime \\
\hline \multirow[t]{2}{*}{$X_{17}$} & Reliability of police services \\
\hline & Pillar: Higher education and training/index: Quality of education \\
\hline \multirow[t]{2}{*}{$X_{18}$} & Quality of the educational system \\
\hline & Pillar: Goods market efficiency/index: Domestic competition \\
\hline$X_{19}$ & Effectiveness of antimonopoly policy \\
\hline$X_{20}$ & Effect of taxation on incentives to invest \\
\hline$X_{21}$ & Relevance of trade barriers \\
\hline \multirow[t]{2}{*}{$X_{22}$} & Business impact of rules on FDI \\
\hline & Pillar: Labour market efficiency/index: Flexibility \\
\hline \multirow[t]{2}{*}{$x_{23}$} & Effect of taxation on incentives to work \\
\hline & Pillar: R\&D Innovation \\
\hline$X_{24}$ & Government procurement of advanced technology products \\
\hline
\end{tabular}

Source: own compilation.

\section{Synthetic evaluation of institutional quality in Central and Eastern European countries in 2016-2017}

In the second stage we elaborated the ranking of Central and Eastern European countries for 2016-2017 using a synthetic measure of development (SMD). This measure allowed constructing the synthetic index of institutional quality (SIIQ) for each country included in the study and capturing countries of similar institutional quality. 
In order to estimate the SIIQ, we performed a preliminary, formal and statistical verification of data and double checked whether the variables are sufficiently highly variable. ${ }^{2}$ Detailed values of the coefficient of variability for each variable are presented in Table 2. Variable $\mathrm{X}_{21}$ has been removed from the set of variables.

Table 2. Numerical characteristics of potential diagnostic data

\begin{tabular}{|c|c|c|c|}
\hline Symbol & Mean & Standard deviation & $\begin{array}{c}\text { Coefficient of variability } \\
\text { (in \%) }\end{array}$ \\
\hline$X_{1}$ & 3.62 & 0.49 & 13.65 \\
\hline$X_{2}$ & 3.90 & 0.53 & 13.62 \\
\hline$X_{3}$ & 3.97 & 0.66 & 16.63 \\
\hline$X_{4}$ & 3.10 & 0.58 & 18.58 \\
\hline$X_{5}$ & 2.51 & 0.51 & 20.20 \\
\hline$X_{6}$ & 4.14 & 0.73 & 17.73 \\
\hline$X_{7}$ & 3.35 & 0.86 & 25.74 \\
\hline$X_{8}$ & 2.59 & 0.54 & 20.91 \\
\hline$X_{9}$ & 2.91 & 0.52 & 17.96 \\
\hline$X_{10}$ & 2.98 & 0.63 & 21.21 \\
\hline$X_{11}$ & 2.96 & 0.56 & 19.01 \\
\hline$X_{12}$ & 2.64 & 0.52 & 19.56 \\
\hline$X_{13}$ & 3.76 & 0.53 & 14.20 \\
\hline$X_{14}$ & 5.41 & 0.57 & 10.05 \\
\hline$X_{15}$ & 4.89 & 0.54 & 11.03 \\
\hline$X_{16}$ & 4.82 & 0.72 & 14.84 \\
\hline$X_{17}$ & 4.32 & 0.70 & 16.25 \\
\hline$X_{18}$ & 3.48 & 0.58 & 16.76 \\
\hline$X_{19}$ & 3.55 & 0.44 & 12.41 \\
\hline$X_{20}$ & 3.31 & 0.54 & 16.31 \\
\hline$X_{21}$ & 4.47 & 0.41 & 9.17 \\
\hline$X_{22}$ & 4.62 & 0.67 & 14.53 \\
\hline$X_{23}$ & 3.12 & 0.46 & 14.73 \\
\hline$X_{24}$ & 2.93 & 0.42 & \\
\hline
\end{tabular}

Source: own compilation with the use of PS IMAGO ver. 24.

The next stage of calculating the institutional quality indicator consists in assessing the correlation between potential diagnostic variables (indicators) to reduce them and make the final choice. To assess the degree of correlation, we deployed the parametric method (for more see, inter alia, Śmiłowska, 1997). As a result, we identified agglomeration with $\mathrm{X}_{1}$ as a central feature and $\mathrm{X}_{6}$ as a satellite feature. Other features: $\mathrm{X}_{2}, \mathrm{X}_{3}, \mathrm{X}_{4}, \mathrm{X}_{5}, \mathrm{X}_{7}, \mathrm{X}_{8}, \mathrm{X}_{9}, \mathrm{X}_{10}, \mathrm{X}_{11}, \mathrm{X}_{12}$,

2 Coefficient of variability calculated based on standard deviation for variables that exceed the threshold value (10\%) means the variables represent sufficient variability. 
$\mathrm{X}_{13}, \mathrm{X}_{14}, \mathrm{X}_{15}, \mathrm{X}_{16}, \mathrm{X}_{17}, \mathrm{X}_{18}, \mathrm{X}_{19}, \mathrm{X}_{20}, \mathrm{X}_{22}, \mathrm{X}_{23}, \mathrm{X}_{24}$ are isolated. For further analysis we selected the central and isolated feature and eliminated the satellite variable $\left(\mathrm{X}_{6}\right)$.

Summing up, for the synthetic assessment of institutional quality in the 17 countries of Central and Eastern Europe we selected 22 diagnostic indicators and eliminated variables $\mathrm{X}_{21}$ and $\mathrm{X}_{6}$. This set of variables represents high information value, sufficient for further analysis. The selected indicators were treated as simulants of institutional quality.

Institutional quality was measured for 17 countries of Central and Eastern Europe. They were grouped based on the standard deviation method. The latter assumes that there is a model object, in which input variables are optimal. The estimation of the model SMD followed the process of arriving at the comparability of diagnostic indicators and the exclusion of negative values. Variables were standardised using classical standardisation:

$$
z_{i j}=\frac{x_{i j}-\overline{x_{j}}}{S_{j}},
$$

where:

$\overline{x_{j}}$ - arithmetic mean of feature $\mathrm{j}$;

$S_{j}$ - standard deviation of feature $\mathbf{j}$;

$z_{i j}$ - standardised value.

Positive values of standardised variables $\left(z_{i j}\right)$ were ensured by the transformation:

$$
z_{i j}=z_{i j}+\varepsilon
$$

where:

$$
\varepsilon=-\min \left\{z_{i j}\right\}+\frac{1}{5} S(z)
$$

and

$S(z)$ - standard deviation of normalised input variables.

Hellwig's method [Panek, 2009] introduces the hierarchy of objects by comparing them to the development model. Coordinates of the model object $\left(z_{0 j}\right)$ are maximum values of standardised variables $\left(z_{i j}\right)$.

$$
z_{0 j}=\max z_{i j} \text { (when the feature is a stimulant). }
$$

The hierarchy of objects is based on how far they are from the model. To calculate the distance between each country and the model we used the Euclidean metric:

$$
d_{i 0}=\sqrt{\sum_{j=1}^{m}\left(z_{i j}-z_{0 j}\right)^{2}}, \mathrm{j}=1,2, \ldots, \mathrm{m} ; \mathrm{i}=1,2, \ldots, \mathrm{n},
$$

where:

$z_{i j}$ - standardised values of diagnostic variables $x_{i j}$; 
$z_{0 j}=\max z_{i j}$ (for stimulants).

In Hellwig's model objects are organised around the SMD value:

$$
s_{i}=1-\frac{d_{i 0}}{d_{0}},
$$

where:

$$
d_{0}=\overline{d_{0}}+2 S_{0}
$$

while:

$$
\begin{gathered}
\overline{d_{0}}=n^{-1} \sum_{i=1}^{n} d_{i 0}, \\
S_{0}=\sqrt{n^{-1} \sum_{i=1}^{n}\left(d_{i 0}-\bar{d}\right)^{2}} .
\end{gathered}
$$

The $s_{i}$ measure usually adopts values from the interval $[0 ; 1]$. The closer we are to the model, the higher the value, which is why it is worth presenting them in the descending order.

Methods of linear ordering that form part of multidimensional comparative analysis or, more broadly, taxonomy, largely origin from the legacy and accomplishments of the Polish school of statistics and econometrics. The first proposal was presented by Z. Hellwig in his work [Hellwig, 1968], where it was used to compare the economic development in selected countries. ${ }^{3}$ This publication initiated intensive investigations in the field and triggered a series of methods of linear ordering proposed in the works [inter alia, of Bartosiewicz, 1976; Borys, 1978; Cieślak, 1974; Nowak, 1984; Pluta, 1976; Strahl, 1978; Walesiak, 1993, Zeliaś, Malina, 1997].

On the grounds of the decision theory (multi-attribute decision making) the first method of linear ordering using the ideal and anti-ideal solution concept was proposed by Hwang and Yoon in 1981 under the name of TOPSIS - Technique for Order Preference by Similarity to Ideal Solution [Hwang, Yoon, 1981]. ${ }^{4}$

There are many methods of creating synthetic variables which use appropriately selected diagnostic variables. Synthetic measures are identified principally to rank objects based on the intensity of a multi-attribute phenomenon. Differences in principles governing the construction of these measures lie mainly in:

- how the account is taken of the attributes of stimulants and destimulants;

- placing attributes within a common comparative system (selection of the normalising formula);

- how the value of attributes of an ideal object is identified;

\footnotetext{
3 One year earlier the proposal was outlined in a non-published Report Procedure of Evaluating high Level Manpower Data and Typology of Countries by Means of the Taxonomic Method (1967).

4 One year earlier the proposal was presented in the following works: K. Yoon, System Selection by Multiple Attribute Decision Making and K. Yoon \& C.L. Hwang, Technique for Order Preference by Similarity to Ideal Solution - A Multiattribute Decision Making.
} 
- how the measure is constructed (analytical form of aggregating function);

- properties of the measure.

Conducted studies have proven that by applying diverse aggregation methods to the same diagnostic variables we receive classifications that are very close as these methods do not significantly impact the order of objects in the study [e.g. Krakowiak-Bal, 2005; Bąk, 2016; Jaworska, Kożuch, 2012].

We selected the Hellwig method because it assumes that coordinates of the ideal solution are the following:

$$
\begin{aligned}
& y_{o j}=\max _{i} y_{i j} \text { when } j \in S \\
& y_{o j}=\min _{i} y_{i j} \text { when } j \in D
\end{aligned}
$$

This assumption is useful in studies on economic development when we may worry that the choice of maximum values is "too good" [Strahl, 1978].

The final stage of calculations divides the objects (countries of Central and Eastern Europe) into classes. Objects are grouped based on the standard deviation method. Variability intervals for the synthetic variable in individual classes are presented in Table 3.

Table 3. Limit values for classes of the synthetic Hellwig's indicator $s_{i}$ of institutional quality in the countries of Central and Eastern Europe in 2016-2017

\begin{tabular}{|l|c|}
\hline Class I & $s_{i} \geq 0.542401$ \\
\hline Class II & $0.542401>s_{i} \geq 0.361601$ \\
\hline Class III & $0.361601>s_{i} \geq 0.1808$ \\
\hline Class IV & $s_{i}<0.1808$ \\
\hline
\end{tabular}

Source: own compilation.

From the study we obtained the values of SIIQ (Table 4), which describes institutional quality and we composed the ranking of institutional quality of Central and Eastern European countries over the period of 2016-2017.

Table 4. SIIQ in Central and Eastern European countries in 2016-2017

\begin{tabular}{|c|l|c|c|}
\hline No. & \multicolumn{1}{|c|}{ Country } & SIIQ $\left(s_{i}\right)$ & Class \\
\hline 1 & Estonia & 0.919745167 & 1 \\
\hline 2 & Czech Rep. & 0.507464977 & 2 \\
\hline 3 & Montenegro & 0.503375132 & 2 \\
\hline 4 & Lithuania & 0.486186318 & 2 \\
\hline 5 & Albania & 0.432018695 & 2 \\
\hline 6 & Poland & 0.402737505 & 2 \\
\hline 7 & Slovenia & 0.396471778 & 2 \\
\hline
\end{tabular}




\begin{tabular}{|r|l|c|c|}
\hline No. & \multicolumn{1}{|c|}{ Country } & SIIQ $\left(s_{i}\right)$ & Class \\
\hline 8 & Latvia & 0.377918454 & 2 \\
\hline 9 & Romania & 0.309934555 & 3 \\
\hline 10 & Hungary & 0.296018543 & 3 \\
\hline 11 & Bulgaria & 0.295916679 & 3 \\
\hline 12 & Serbia & 0.270080749 & 3 \\
\hline 13 & Slovakia & 0.266417795 & 3 \\
\hline 14 & Moldova & 0.203149432 & 4 \\
\hline 15 & Croatia & 0.198540252 & 4 \\
\hline 16 & Ukraine & 0.163778136 & 4 \\
\hline 17 & Bosnia \&Herzegovina & 0.117462092 & 3 \\
\hline
\end{tabular}

Source: own calculations from the Excel spread sheet.

Based on the SIIQ, we may conclude that the highest institutional quality is offered to potential investors in Estonia (class I), where Hellwig's indicator reaches 0.919745167. The SIIQ for Estonia is clearly the highest, much higher than the average SIIQ for other countries of Central and Eastern Europe.

Figure 4. Ranking by standardised SIIQ values in the countries of CEECs in 2016-2017

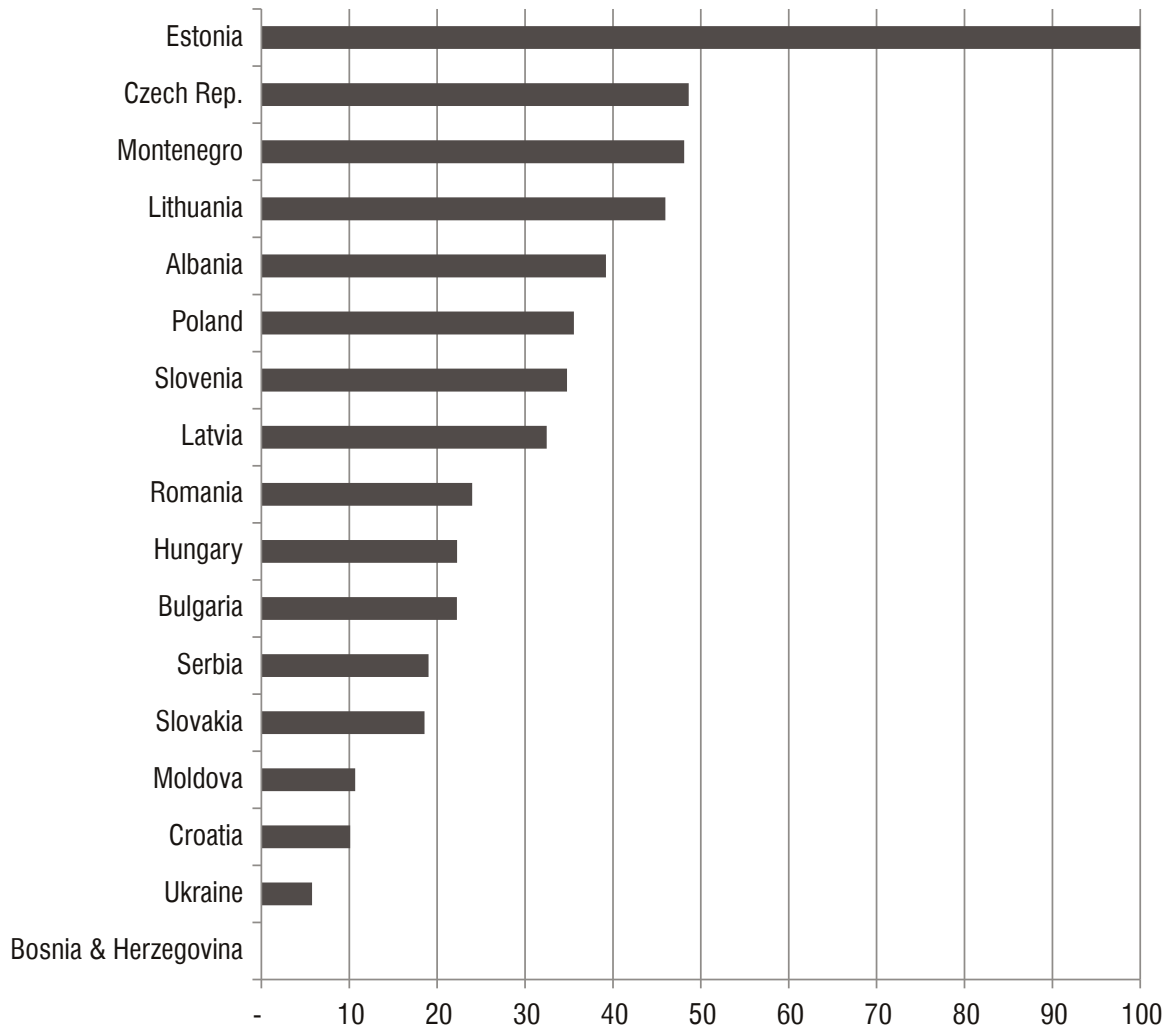

Source: own compilation. 
Class II contains 7 countries: the Czech Republic, Montenegro, Lithuania, Poland, Slovenia, Latvia, and Albania. The Czech Republic ranks first in this class with the maximum value of institutional quality indicator of 0.507464977 . At the bottom of class II there is Latvia with the institutional quality indicator of 0.377918454 .

Class III consists of countries offering medium institutional quality to potential investors: Romania, Hungary, Bulgaria, Serbia, Slovakia, and Moldova. The lowest institutional quality in Central and Eastern Europe was ensured to investors in 3 countries: Croatia, Ukraine and Bosnia \& Herzegovina, which belong to class IV in the ranking.

To better demonstrate differences in the SIIQ in the countries of Central and Eastern Europe in 2016-2017, these values were standardised in such a way that the country with the highest SIIQ scored 100 and other countries proportionally less (Figure 4).

\section{Institutional quality offered to potential investors and FDI inward stock as \% of GDP}

In the third stage of our study we focused on the relationship between the quality of institutions in the countries of Central and Eastern Europe and FDI inward stock as \% of GDP in 2016-2017. To this end we examined the correlation between SIIQ (constructed in the second stage of the study) and FDI inward stock as \% of GDP. Correlation analysis started with the correlation diagram for the tested variables (Figure 5).

Figure 5. Correlation between SIIQ and FDI inward stock as \% of GDP

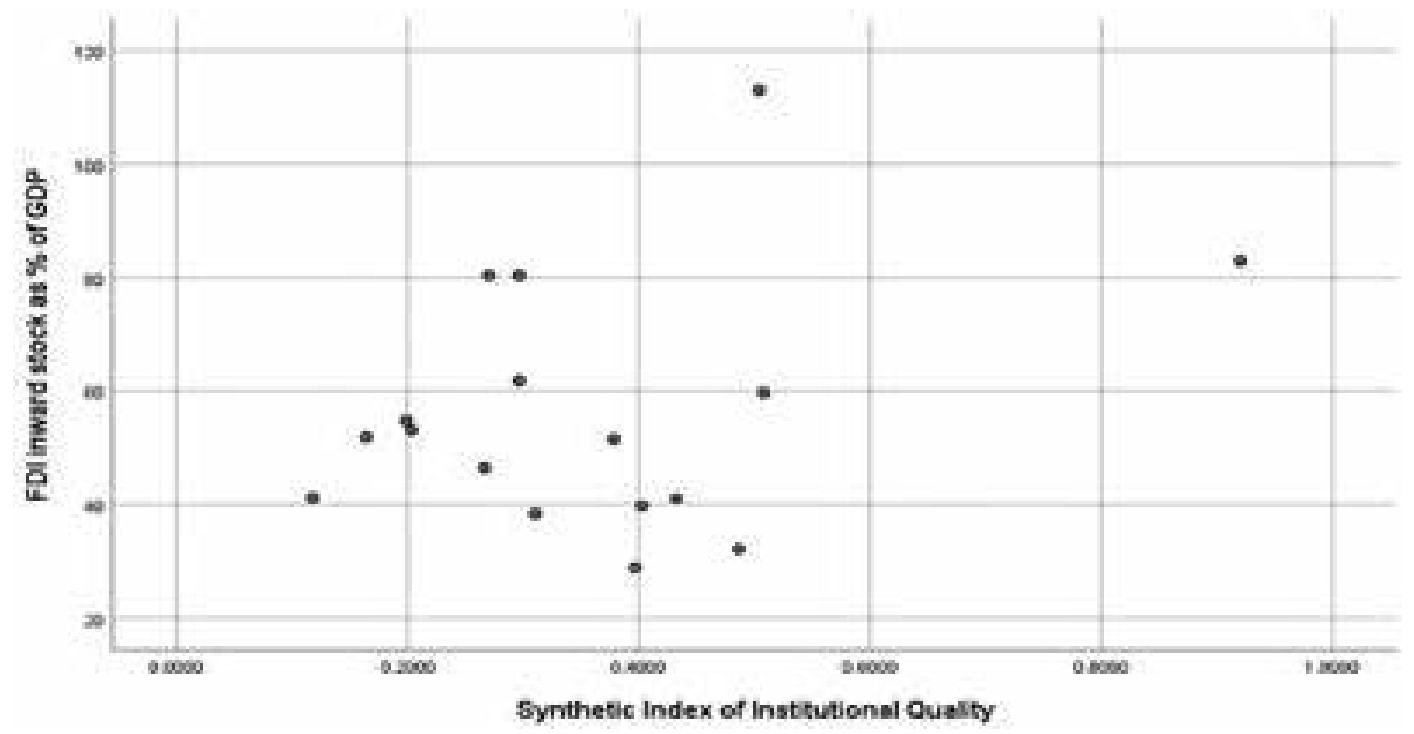

Source: own compilation using PS IMAGO. 
Evaluation of the distribution suggests a positive correlation between the tested variables. Increases in SIIQ usually trigger increases in FDI inward stock as \% of GDP.

The distribution of the countries of Central and Eastern Europe between classes of institutional quality distinguished based in the SIIQ and FDI inward stock as \% of GDP is shown in the cross table (Table 5). By examining the data included in it we may assume that countries offering higher institutional quality to potential investors have usually higher FDI inward stock as \% of GDP (e.g. Estonia), although there are exceptions (e.g. Romania, Hungary).

Table 5. Distribution of Central and Eastern Europe countries between classes of institutional quality and FDI inward stock as \% of GDP

\begin{tabular}{|c|c|c|c|c|}
\hline \multirow[b]{2}{*}{ Institutional quality classes } & \multicolumn{3}{|c|}{ FDI inward stock as \% of GDP } & \multirow[b]{2}{*}{ Total } \\
\hline & $\begin{array}{l}\text { High } \\
\text { Montenegro, Serbia, } \\
\text { Bulgaria, Estonia }\end{array}$ & $\begin{array}{c}\text { Middle } \\
\text { Czech Rep., Latvia, } \\
\text { Hungary, Moldova, } \\
\text { Croatia, Ukraine }\end{array}$ & $\begin{array}{c}\text { Low } \\
\text { Poland,Romania, Slovakia, } \\
\text { Albania, Bosnia \& Herzegovina, } \\
\text { Lithuania, Slovenia }\end{array}$ & \\
\hline $\begin{array}{l}\text { Class I } \\
\text { Estonia }\end{array}$ & 1 & 0 & 0 & 1 \\
\hline $\begin{array}{l}\text { Class II } \\
\text { Czech Rep., Montenegro, Lithuania, } \\
\text { Albania, Poland, Slovenia, Latvia }\end{array}$ & 1 & 2 & 4 & 7 \\
\hline $\begin{array}{l}\text { Class III } \\
\text { Romania, Hungary, Bulgaria, Serbia, } \\
\text { Slovakia, Moldova }\end{array}$ & 2 & 2 & 2 & 6 \\
\hline $\begin{array}{l}\text { Class IV } \\
\text { Croatia, Ukraine, Bosnia \& Herzegovina }\end{array}$ & 0 & 2 & 1 & 3 \\
\hline Total & 4 & 6 & 7 & 17 \\
\hline
\end{tabular}

Source: own compilation.

To assess how strong is the correlation between the class of institutional quality of a given country and FDI inward stock as \% of GDP we used the eta coefficient. ${ }^{5}$ Its value for the study was $0.447 .{ }^{6}$ In conclusion, there is a moderate positive correlation between the class of institutional quality of a given country and FDI inward stock as \% of GDP. By ensuring higher institutional quality, Central and Eastern Europe countries increase FDI inward stock as \% of their GDP.

\section{Summary}

The above overview of the subject-matter literature proves that the institutional environment is one of the factors decisive for the investment attractiveness of countries. Our study, however, was not intended to be yet another attempt to prove or dismiss this knowledge but

5 Eta coefficient can be calculated for linear and non-linear relationship between variables. Dependent variable must be measurable while independent variable may be either measurable or non-measurable. The coefficient ranges from 0 to 1 . If there is no correlation, $e_{y x}=0$. The closer its value to 1 , the stronger the correlation.

6 Own calculations using the PS IMAGO. 
to find out which institutional factors are relevant for FDI inflow. To this end, we examined several dozen variables that describe the efficiency of public institutions. We investigated Central and Eastern Europe countries which, besides geographical location, share common experiences of a more or less successful transformation from the centrally planned to market economy and cooperate within various international institutions and organizations (e.g. EU, V4, NATO, OECD).

Institutional quality of the 17 countries of Central and Eastern Europe was assessed using Hellwig's synthetic measure of development. It was used to construct an original synthetic index of institutional quality (SIIQ). The study helped us create a ranking and distinguish four uniform classes of institutional quality in the CEECs. The data, rankings and analyses have led us to the following conclusions:

1) Central and Eastern European countries differ with respect to the efficiency with which they attract FDI; those which were in the forefront of the systemic transformation and integrated with Western Europe by joining the EU represent (with some exceptions) the highest efficiency in attracting FDI.

2) Similar conclusions can be drawn from comparisons of the rankings of institutional quality. Estonia is the undisputed leader in the region, both in the overall and in the detailed rankings.

3) The quality of institutions is closely linked, although to a different degree, with FDI inward stock as \% of GDP. Higher SIIQ usually triggers increases in FDI (e.g. Estonia), although there are exceptions (e.g. Romania, Hungary). It may mean that when drawing conclusions we need to consider, inter alia, the size of the country because in smaller communities the likelihood of atypical results increases. On top of that, the study was conducted based on averaged variables for each country. Thus, it fails to provide information about the differentiation of institutional quality within a particular country.

According to the authors, SIIQ is a valuable tool to synthetically assess institutional quality. Looking at dynamic changes in the global economy, we need to expect that the future dependence between social and economic development and institutional quality will deepen. This is why it is necessary to systematically measure, evaluate and develop the methodology of evaluating institutional quality of countries. Results of studies may provide valuable input into the economic policy making and improve public administration performance in relations with foreign investors.

The obtained results justify the need to continue the research to focus on an in-depth quantitative analysis, which will demonstrate the power of the impact of individual variables. It also seems justified to expand the study with other groups of countries. 


\section{References}

1. Acemoglu, D., Johnson, S., Robinson, J. (2004). Institutions as a Fundamental Cause of Long-Run Growth. NBER Working Paper, Vol. 10481, pp. 1-111.

2. Akcay, S. (2001). Is Corruption an Obstacle for Foreign Investors in Developing Countries? A Cross-Country Evidence. Yapi Kredi Economic Review, Vol. 12(2), pp. 27-34.

3. Alesina, A., Perotti, R. (1996). Income distribution, political instability and investment. European Economic Review, Vol. 40(6), pp. 1203-1228.

4. Ali, F., Fiess, N., MacDonald, R. (2010). Do institutions matter for foreign direct investment? Open Economies Review, Vol. 21(2), pp. 201-219.

5. Al-Sadig, A. (2009). The Effects of Corruption on FDI Inflows. Cato Journal, Vol. 29(2), pp. 267-294.

6. Bailey, N. (2018). Exploring the relationship between institutional factors and FDI attractiveness: A meta-analytic review. International Business Review, Vol. 27(1) pp. 139-148.

7. Bąk, A. (2016). Metody porządkowania liniowego w polskiej taksonomii - pakiet Porządkowanie liniowe obiektów metodą Hellwiga i TOPSIS - analiza porównawcza. Prace Naukowe Uniwersytetu Ekonomicznego we Wrocławiu, Vol. 426, pp. 13-22.

8. Bański, J. (2008). Polska i Europa Środkowo-Wschodnia w koncepcjach podziału Europy. In: P. Eberhardt (Ed.) Problematyka geopolityczna ziem polskich. Prace Geograficzne, Vol. 218, 121-134.

9. Bartosiewicz, S. (1976). Propozycja metody tworzenia zmiennych syntetycznych. Prace Naukowe Akademii Ekonomicznej we Wrocławiu, Vol. 84, pp. 5-7.

10. Bénassy-Quéré, A., Coupet, M., Mayer, T. (2005). Institutional Determinants of Foreign Direct Investment. CEPII Working Paper, Vol. 05, pp. 1-30.

11. Bénassy-Quéré, A., Fontagné, L., Lahrèche-Révil, A. (2003). Tax Competition and Foreign Direct Investment. CEPII Working Paper, Vol. 17, pp. 1-32.

12. Borys, T. (1978). Propozycja agregatowej miary rozwoju obiektów. Przegląd Statystyczny, Vol. 3, pp. 371-381.

13. Bruno, R.L. (2008). Rule of Law, Institutional Quality and Information. DARRT. University of Bologna, IZA Discussion Paper, Vol. 3497, pp. 1-32.

14. Buchanan, B. G, Le, Q.V., Rishi, M. (2012). Foreign direct investment and institutional quality: Some empirical evidence. International Review of Financial Analysis, Vol. 21, pp. 81-89.

15. Busse, M., Hefeker, C. (2007). Political risk, institutions and foreign direct investment. European Journal of Political Economy, Vol. 23(2) pp. 397-415.

16. Busse, M. (2004). Transnational Corporations and Repression of Political Rights and Civil Liberties: An Empirical Analysis, Kyklos, Vol. 57(1), pp. 45-66.

17. Cieślak, M. (1974). Taksonomiczna procedura prognozowania rozwoju gospodarczego i określania potrzeb na kadry kwalifikowane. Przegląd Statystyczny, Vol. 1, pp. 29-39.

18. Cosset, J., Suret, J. (1995). Political risk and benefits of international portfolio diversification. Journal of International Business Studies, Vol. 26(2), pp. 301-318. 
19. Daniele, V., Marani, U. (2006). Do institutions matter for FDI: A comparative analysis of the MENA countries. MPRA Paper, Vol. 2426, pp. 1-28.

20. Daude, C., Stein, E. (2007). The quality of institutions and foreign direct investment. Economics \& Politics, Vol. 19(3), pp. 317-344.

21. Egger, P., Winner, H. (2005). Evidence on corruption as an incentive for foreign direct investment. European Journal of Political Economy, Vol. 21, pp. 932-952.

22. Essien, J., Barikui, T., Abuba, S., Igbara, F. (2015). The Impact of National Security on Foreign Direct Investment (FDI) In Nigeria. IOSR Journal of Business and Management, Vol. 17(5), pp. 69-74.

23. Fabry, N., Zeghni, S. (2006). How former communist countries in Europe attract inward foreign direct investment? A matter of institutions. Communist and Post-Communist Studies, Vol. 2, pp. 201-219.

24. Fatica, S. (2009). Taxation and the quality of institutions: asymmetric effects on FDI. Taxation paper, Working Paper, Vol. 21, pp. 1-59.

25. Feld, L.P., Heckemeyer, J.H. (2008). FDI and Taxation. A Meta-Study. ZEW Discussion Paper, 08-128, pp. 1-57.

26. Francis, J., Zheng, C., Mukherji, A. (2009). An institutional perspective on foreign direct investment: A multi-level framework. Management International Review, Vol. 49(5), pp. 565-583.

27. Globerman, S., Shapiro, D. (2003). Governance infrastructure and US foreign direct investment. Journal of International Business Studies, Vol. 34(1), pp. 19-39.

28. Habib, M., Zurawicki, L. (2010). Corruption and Foreign Direct Investment: What Have We Learned. International Business \& Economics Research Journal, Vol. 9(7), pp. 1-9.

29. Halecki, O. (1994). Historia Europy - jej granice i podziały. Lublin: Instytut Europy Środkowo-Wschodniej.

30. Hausmann, R., Fernández-Arias, E. (2000). Foreign Direct Investment: Good Cholesterol? Inter American Development Bank Working Papers, 417, pp. 1-46.

31. Hellwig, Z. (1968). Zastosowanie metody taksonomicznej do typologicznego podziału krajów ze względu na poziom ich rozwoju oraz zasoby i strukturę wykwalifikowanych kadr. Przegląd Statystyczny, Vol. 4, pp. 307-327.

32. Hwang, C.L., Yoon, K. (1981). Multiple Attribute Decision Making: Methods and Applications. New York: Springer-Verlag.

33. Jaspersen, F., Aylward, A., Knox, A. (2000). The effects of risk on private investment: Africa compared with other developing areas. In: P. Collier \& C. Pattillo (Eds.), Investment and risk in Africa (pp. 71-95). New York: St Martin's Press.

34. Jaworska, M., Kożuch, A.J. (2012). Ocena przydatności wybranych metod WAP w analizie samodzielności finansowej gmin. Metody ilościowe w badaniach ekonomicznych, Vol. XIII/1, pp. 131-137.

35. Jensen, N. (2008). Political Risk, Democratic Institutions, and Foreign Direct Investment. The Journal of Politics, Vol. 70(04), pp. 1040-1052.

36. Jude, C., Levieuge, G. (2015). Growth effect of FDI in developing economies: The role of institutional quality. Direction Générale Des Études et des Relations Internationales, Banque de France, pp. 1-33. 
37. Kaufman, D., Kraay, A., Mastruzzi, M. (2005). Governance Matters IV: Governance Indicators 1996-2004. Washington, DC: World Bank.

38. Khan, M.A., Samad, G. (2010). Intellectual Property Rights and Foreign Direct Investment: Analysis of 14 South and South East Asian Countries, 1970-2005. Applied Econometrics and International Development, Vol. 10-1, pp. 219-230.

39. Klimek, A. (2015). Poland Institutions and Outward Foreign Direct Investment. International Journal of Management and Economics, Vol. 46, pp. 101-119.

40. Kolstad, I., Wiig, A. (2009). What determines Chinese outward FDI? Journal of World Business, Vol. 47, pp. 26-34.

41. Krakowiak-Bal, A. (2005). Wykorzystanie wybranych miar syntetycznych do budowy rozwoju infrastruktury technicznej. Infrastruktura i Ekologia Terenów Wiejskich, Vol. 3, pp. 71-82.

42. Kurul, Z., Yalta, A.Y. (2017). Relationship between Institutional Factors and FDI Flows in Developing Countries: New Evidence from Dynamic Panel Estimation. Economies, Vol. 5(2), pp. 1-10.

43. Lee, M., Park, D. (2013). Intellectual Property Rights, Quality of Institutions, and Foreign Direct Investment into Developing Asia. ADB Economics Working Paper Series, Vol. 354, pp. 1-16.

44. Lemma, T.T., Negash, M. (2013). Institutional, macroeconomic and firm-specific determinants of capital structure: The African evidence. Management Research Review, Vol. 36(11), pp. 1081-1122.

45. Levchenko, A. (2004). Institutional Quality and International Trade, HIMF Working Paper, 04/231, pp. 1-47.

46. Mohamed, S.E., Sidiropoulos, M. (2010). Another Look at the Determinants of Foreign Direct Investment in MENA Countries: An Empirical Investigation. Journal of Economic Development, Vol. 35(2), pp. 75-95.

47. Moore, M. (1998). Death without Taxes: Democracy, State Capacity, and Aid Dependency in the Fourth World. In: G. White, M. Robinson (Eds.), Towards a Democratic Developmental State. Oxford University Press.

48. Nielsen, BB., Asmussen, Ch.G., Weatherall, C.D. (2017). The location choice of foreign direct investments: Empirical evidence and methodological challenges. Journal of World Business, Vol. 52, pp. 62-82.

49. Nowak, E. (1984). Problemy doboru zmiennych do modelu ekonometrycznego. Warszawa: Wydawnictwo Naukowe PWN.

50. Ostergren, R.C., Rice, J.G. (2004). The Europeans. A geography of People. Culture and environment. New York: The Guilford Press.

51. Panek, T. (2009). Statystyczne metody wielowymiarowej analizy porównawczej. Warszawa: Szkoła Główna Handlowa w Warszawie - Oficyna Wydawnicza.

52. Petersen, N. (2011). Antitrust Law and the Promotion of Democracy and Economic Growth. Preprints of the Max Planck Institute for Research on Collective Goods, Bonn, pp. 1-44.

53. Pluta, W. (1976). Taksonomiczna procedura prowadzenia syntetycznych badań porównawczych za pomocą zmodyfikowanej miary rozwoju gospodarczego. Przegląd Statystyczny, Vol. 4, pp. 511-517. 
54. Pournarakis, M., Varsakelis, N.C. (2002). Foreign Direct Investment in Central and Eastern European Countries: Do Institutions Matter? Presented at the EIBA Annual Conference. Athens, Greece. Retrieved from: http:// citeseerx.ist.psu.edu/viewdoc/download?doi=10.1.1.195.993\&re$\mathrm{p}=$ rep1\&type $=$ pdf [accessed: 20.05.2018].

55. Rigobon, R., Rodrik, D. (2004). Rule of Law, Democracy, Openness, and Income: Estimating the Interrelationships. NBER Working Paper, 10750, pp. 1-28.

56. Rodrik, D., Subramanian, A., Trebbi, F. (2004). Institutions Rule: The Primacy of Institutions over Geography and Integration in Economic Development. Journal of Economic Growth, Vol. 9, pp. 131-165.

57. Rószkiewicz, M. (2002). Metody ilościowe w badaniach marketingowych. Warszawa: Wydawnictwo Naukowe PWN.

58. Śmiłowska, T. (1997). Statystyczna analiza poziomu życia ludności Polski w ujęciu przestrzennym. Warszawa: Główny Urząd Statystyczny. Zakład Badań Statystyczno-Ekonomicznych.

59. Sobczyk, M. (2000). Statystyka. Podstawy teoretyczne przykłady - zadania. Lublin: Wydawnictwo UMCS.

60. Stoian, R.C., Vickerman, R. (2005). The Interplay between Foreign Direct Investment, Security and European Integration: The Case of the Central and Eastern European Countries. Proceedings in Academy of International Business Annual Meeting, Quebec, CanadaRetrieved from: http://kar.kent.ac.uk/9873/ [accessed: 15.05.2018].

61. Strahl, D. (1978). Propozycja konstrukcji miary syntetycznej. Przeglad Statystyczny, Vol. 2, pp. 205-215.

62. Tanaka, H., Iwaisako, T. (2014). Intellectual property rights and foreign direct investment: A welfare analysis. European Economic Review, Vol. 67, pp. 107-124.

63. Tuman, J., Emmert, C. (2004). The political economy of U.S. Foreign Direct Investment in Latin America: A Reappraisal. Latin American Research Review, Vol. 39(3), p. 9-28.

64. Walesiak, M. (1993). Statystyczna analiza wielowymiarowa w badaniach marketingowych. Prace Naukowe Akademii Ekonomicznej we Wrocławiu, 654(101), pp. 1-117.

65. Walsh, J.W., Yu, J. (2010). Determinants of Foreign Direct Investment: A Sectoral and Institutional Approach. IMF Working Paper, 10/187, pp. 1-26.

66. Wang, Y., Cheng, L., Wang, H., Li, L. (2014). Institutional quality, financial development and OFDI. Pacific Science Review, Vol. 16(2), pp. 127-132.

67. Zeliaś, A., Malina, A. (1997). O budowie taksonomicznej miary jakości życia. Taksonomia, Vol. 4, pp. 238-262. 